\title{
Uptake, accumulation and metabolization of the antidepressant fluoxetine by Mytilus galloprovincialis ${ }^{\text {is }}$
}

\author{
Liliana J.G. Silva ${ }^{\mathrm{a},}{ }^{*}$, Margarida C. Martins ${ }^{\mathrm{a}}$, André M.P.T. Pereira ${ }^{\mathrm{a}}$, Leonor M. Meisel ${ }^{\mathrm{b}}$, \\ Maria Gonzalez-Rey ${ }^{c}$, Maria João Bebianno ${ }^{c}$, Celeste M. Lino ${ }^{\mathrm{a}}$, Angelina Pena ${ }^{\mathrm{a}}$ \\ ${ }^{a}$ LAQV, REQUIMTE, Group of Bromatology, Pharmacognosy and Analytical Sciences, Faculty of Pharmacy, University of Coimbra, Polo III, Azinhaga de St ${ }^{a}$ \\ Comba, 3000-548 Coimbra, Portugal \\ ${ }^{\mathrm{b}}$ Department of Pharmacology, Faculty of Pharmacy, University of Lisbon, Av. Prof. Gama Pinto, 1649-003 Lisboa, Portugal \\ c CIMA, Faculty of Science and Technology, University of Algarve, Faro, Campus de Gambelas, 8000-135 Faro, Portugal
}

\section{A R T I C L E I N F O}

\section{Article history:}

Received 8 September 2015

Received in revised form

11 February 2016

Accepted 11 February 2016

Available online 3 March 2016

\section{Keywords:}

Fluoxetine

Metabolization

Bioconcentration factor

Mytilus galloprovincialis.

\begin{abstract}
A B S T R A C T
Fluoxetine, a selective serotonin re-uptake inhibitor (SSRI) antidepressant, is among the most prescribed pharmaceutical active substances worldwide. This study aimed to assess its accumulation and metabolization in the mussel Mytillus galloprovincialis, considered an excellent sentinel species for traditional and emerging pollutants. Mussels were collected from Ria Formosa Lagoon, Portugal, and exposed to a nominal concentration of fluoxetine $\left(75 \mathrm{ng} \mathrm{L}^{-1}\right)$ for 15 days. Approximately $1 \mathrm{~g}$ of whole mussel soft tissues was extracted with acetonitrile:formic acid, loaded into an Oasis MCX cartridge, and fluoxetine analysed by liquid chromatography with tandem mass spectrometry (LC-MSn). After 3 days of exposure, fluoxetine was accumulated in $70 \%$ of the samples, with a mean of $2.53 \mathrm{ng} \mathrm{g}^{-1}$ dry weight (d.w.) and norfluoxetine was only detected in one sample (10\%), at $3.06 \mathrm{ng} \mathrm{g}^{-1}$ d.w. After 7 days of exposure, the accumulation of fluoxetine and norfluoxetine increased up to 80 and 50\% respectively, and their mean accumulated levels in mussel tissues were up to 4.43 and $2.85 \mathrm{ng} \mathrm{g}^{-1}$ d.w., respectively. By the end of the exposure period ( 15 days), both compounds were detected in $100 \%$ of the samples (mean of 9.31 and $11.65 \mathrm{ng} \mathrm{g}^{-1}$ d.w., respectively). Statistical analysis revealed significant accumulation differences between the 3rd and 15th day of exposure for fluoxetine, and between the 3rd and 7th against the 15th day of exposure for norfluoxetine. These results suggest that the fluoxetine accumulated in mussel tissues is likely to be metabolised into norfluoxetine with the increase of the time of exposure, giving evidence that at these realistic environmental concentrations, toxic effects of fluoxetine in mussel tissues may occur.
\end{abstract}

(๑) 2016 Elsevier Ltd. All rights reserved.

\section{Introduction}

According to the latest report of 2011 of the Organisation for Economic Co-Operation and Development (OECD), the consumption of antidepressants increased more than $60 \%$ over the past decade (Silva et al., 2012). Selective serotonin re-uptake inhibitors (SSRIs), widely marketed since the mid-1980s (Schultz and Furlong, 2008), include fluoxetine that is among the most prescribed pharmaceutical active substance at national level and worldwide. Fluoxetine, as the other SSRIs, is primarily prescribed to patients

\footnotetext{
This paper has been recommended for acceptance by Eddy Y. Zeng.

* Corresponding author.

E-mail address: ljgsilva@hotmail.com (L.J.G. Silva).
}

diagnosed with clinical depression, obsessive-compulsive disorder, panic disorder, social phobia, and attention-deficit disorder (Schultz and Furlong, 2008). In mammals, following oral ingestion, fluoxetine is metabolized and the primary metabolite formed is $\mathrm{N}$ desmethyl product (norfluoxetine) which is more potent than the parent compound (Silva et al., 2012).

One of the main inputs of pharmaceutical compounds to natural waters is from wastewater treatment plants (WWTPs) (Silva et al., 2012). The annual rate of discharge of pharmaceuticals from municipal WWTPs may reach kilogram levels (Paterson and Metcalfe, 2008). Furthermore, fluoxetine concentrations ranging from 0.41 to $141 \mathrm{ng} \mathrm{L}^{-1}$ were already reported in surface waters from Canada, Spain and USA (Silva et al., 2012). Under chronic exposure conditions, there is potential for pharmaceuticals to accumulate in fish and in other aquatic organisms (Paterson and 
Metcalfe, 2008) and a range of 79.1-9.8 $\mathrm{ngg}^{-1}$ wet weight (w.w.) of fluoxetine was reported to be accumulated in Elliptio spp. mussels from Crabtree Creek, USA, near a WWTP effluent channel and the downstream sites (Bringolf et al., 2010). Along with its main metabolite, norfluoxetine, fluoxetine is undoubtedly the SSRI most investigated, both in the aquatic compartments and in biota (Silva et al., 2012) and was reported as the most toxic (Brooks et al., 2003), at levels of at least one order of magnitude lower when compared with the other SSRIs (Silva et al., 2015).

The phylogenetically ancient and highly conserved neurotransmitter and neurohormone serotonin has been found in vertebrates and invertebrates, although its specific physiological role and mode of action is unknown for many species (Kreke and Dietrich, 2008). SSRIs affects a wide range of aquatic organisms, both vertebrate and invertebrate, but there is large variation in the sensitivity of organisms (Sumpter et al., 2014). By increasing the bioavailability of serotonin, fluoxetine has been described to disrupt the endocrine systems and many biological functions within invertebrates, such as reproduction, metabolism, moulting and behaviour (Bossus et al., 2014; Fong and Ford, 2014; Silva et al., 2015).

The first data on fluoxetine and norfluoxetine accumulation in brain, liver, and muscle tissues of different fish species of effluentdominated ecosystems was reported by Brooks et al. (2005). Since then, some studies reported fluoxetine accumulation in fish tissues (Silva et al., 2015) and fewer on refer other aquatic organisms, such as mussels (Bringolf et al., 2010; Franzellitti et al., 2014; Maruya et al., 2014).

Fluoxetine, with basic characteristics, binds easily with particulate materials (Zenker et al., 2014). Thus, dietary routes of fluoxetine exposure and uptake may be particularly important for bivalves (Franzellitti et al., 2014). Bivalves are filter feeders sessile organisms which draw in water and particles from their surrounding environment (Dodder et al., 2014). There is still a paucity of data regarding accumulation and metabolization of pharmaceuticals, such as fluoxetine, by bivalves and these mechanisms deserve additional clarification (Boxall et al., 2012; Franzellitti et al., 2014; Du et al., 2015). The blue mussel Mytilus galloprovincialis is generally considered a good bioindicator of environmental quality and of accumulation of numerous contaminants (Bebianno et al., 2015). In addition, the exposure to fluoxetine has clearly triggered several biological responses in this species, namely endocrine disruption (Gonzalez-Rey and Bebianno, 2013). Therefore, the aim of this study was to evaluate the uptake, accumulation, and metabolization of fluoxetine in mussels, $M$. galloprovincialis, exposed to an environmental realistic concentration of fluoxetine (75 $\mathrm{ng} \mathrm{L}^{-1}$ ) to complement previous findings. To our knowledge, this is the first study reporting the metabolization of this pharmaceutical in bivalves (mussels).

\section{Materials and methods}

\subsection{Standards and chemicals}

Reference standards of fluoxetine and norfluoxetine hydrochloride, the labelled surrogates fluoxetine-d5 hydrochloride, and norfluoxetine-d6 oxalate, all with $\geq 98 \%$ purity, were purchased from Sigma-Aldrich (St. Louis, MO, USA). Stock and intermediate solutions were prepared in methanol at $5 \mathrm{mg} \mathrm{mL}^{-1}$ and $250 \mu \mathrm{g} \mathrm{mL}^{-1}$, respectively, and stored at $-20^{\circ} \mathrm{C}$, for a maximum of 6 months. Mixed standard working solutions, renewed before each analytical run, were prepared at 2.5 and $50 \mathrm{ng} \mathrm{mL}^{-1}$ in methanol:water (10:90), and used for linearity, accuracy, and repeatability assays. The labelled surrogates were typically prepared to obtain a final concentration of $50 \mathrm{ng} \mathrm{mL}^{-1}$.

HPLC-grade acetonitrile and methanol were purchased from
Sigma-Aldrich (St. Louis, MO, USA). Water was prepared from a Millipore Milli Q system (Bedford, MA, USA). Ammonium hydroxide and formic acid (98\%) were obtained from Merck (Darmstadt, Germany); hydrochloric acid 37\% was from Carlo Erba (Milan, Italy).

\subsection{Sample collection and exposure assay}

Mussels M. galloprovincialis were collected from a small fishing and tourist boats harbour in the Ria Formosa Lagoon, Portugal $\left(37^{\circ} 06^{\prime} 58.5^{\prime \prime} \mathrm{N} 7^{\circ} 37^{\prime} 44.0^{\prime \prime} \mathrm{W}\right)$. Mussels were transported alive to the laboratory, the shell was cleaned, and they were acclimatized for one week in aerated natural seawater. Mussels were then separated and placed in several aquaria $\left(n=35,1\right.$ mussel $\left.L^{-1}\right)$; four for controls (un-exposed) and three exposed to a nominal concentration of fluoxetine $\left(75 \mathrm{ng} \mathrm{L}^{-1}\right)$. The aquaria were kept at constant temperature $\left(18.6{ }^{\circ} \mathrm{C} \pm 1\right)$, salinity $(33 \pm 0.4), \mathrm{pH}(8.1 \pm 0.2)$ and oxygen saturation $(>98 \% \pm 2)$. Mussels were not fed until the end of the experiment and no mortality occurred. Water was changed every $48 \mathrm{~h}$ and fluoxetine concentration re-established (Gonzalez-Rey and Bebianno, 2013).

At each sampling time $(0,3,7$, and 15 days), mussels $(\mathrm{n}=10)$ were removed from control and exposed aquaria, freeze-dried and individually stored at $-20{ }^{\circ} \mathrm{C}$ to determine fluoxetine accumulated in mussel tissues. Fifteen mussels were removed from each aquaria and individual shell biometric measured - average shell length size: $67.60 \pm 5.08 \mathrm{~mm}$, width: $37.31 \pm 1.77 \mathrm{~mm}$ and height $25.48 \pm 1.93$ (Table S1, Supporting Information) and the Condition index $(\mathrm{CI})$ quantified as the ratio shown in equation (1). Data is presented in Table S1.

$$
\begin{aligned}
\mathrm{CI}(\%)= & {[\text { whole soft tissue }(\mathrm{w} . \mathrm{w} .) \times \text { whole body tissue }} \\
& \text { with shell } \left.(\text { w.w. })^{-1}\right] \times 100
\end{aligned}
$$

\subsection{Experimental procedure}

Each mussel whole soft tissues was grounded into powder, and $\pm 1 \mathrm{~g}$ was homogenized and spiked with surrogate standards (fluoxetine-d5 and norfluoxetine- $d 6$ ) and extracted twice with $10 \mathrm{~mL}$ acetonitrile with $0.1 \%$ formic acid (Schultz et al., 2010). After mixing for $5 \mathrm{~min}$, ultrasonication for $15 \mathrm{~min}$, and centrifugation for $10 \mathrm{~min}$ at $4{ }^{\circ} \mathrm{C}$ and $5400 \mathrm{~g}$, the supernatant was collected and the extraction repeated. The supernatants were finally pooled and centrifuged for $10 \mathrm{~min}$ at $4{ }^{\circ} \mathrm{C}$ and $20,000 \mathrm{~g}$. For solid phase extraction with Oasis MCX cartridge $(150 \mathrm{mg}, 6 \mathrm{~mL}$, Waters, Milford, MA, USA), the extract was loaded into the cartridge previously conditioned with $5 \mathrm{~mL}$ methanol and $5 \mathrm{~mL}$ acidified water at $\mathrm{pH} 2.5$. To rinse $2 \mathrm{~mL} 0.1 \mathrm{~N} \mathrm{HCl}$ and $2 \mathrm{~mL} 5 \%$ methanol in water were used. Elution was done with $2 \mathrm{~mL}$ methanol following $6 \mathrm{~mL} \mathrm{5 \%} \mathrm{ammo-}$ nium hydroxide in methanol. Finally, the eluate was evaporated to dryness under a gentle stream of nitrogen, at $40{ }^{\circ} \mathrm{C}$, and the dried extracts were stored at $-20^{\circ} \mathrm{C}$ until analysis, that took place in $48 \mathrm{~h}$ maximum.

For liquid chromatography coupled to tandem mass spectrometry (LC-MSn) analysis, the dried eluate was reconstituted in $1 \mathrm{~mL}$ methanol:water (10:90) and microfiltered through durapore membrane filters $0.22 \mu \mathrm{m}$ (Millipore, Milford, MA, USA). A $20 \mu \mathrm{L}$ injection volume was used with a flow rate at $200 \mu \mathrm{L} \mathrm{min}^{-1}$ and a gradient of $(A)$ water with $0.5 \%$ formic acid and (B) methanol with $0.5 \%$ formic acid, as presented in Table S2. A chromatographic column ZORBAX Eclipse XDB-Phenyl $(150 \times 3.0 \mathrm{~mm}$; $3.5 \mu \mathrm{m})$, maintained at $45{ }^{\circ} \mathrm{C}$, and guard-column of the same packing material were used. A hybrid Quadrupole Ion Trap Mass Spectrometer (LCQ 
Advantage MAX, Thermo Finnigan, San Jose, California, USA) was operated in the positive electrospray ionization (ESI) mode using selected reaction monitoring (SRM) acquisition. Source and capillary temperatures were set at 0 and $220^{\circ} \mathrm{C}$ and voltages at 4.5 and $34 \mathrm{~V}$, respectively. Nitrogen was used as nebulizing gas, with a sheath gas flow of 40 (arbitrary unit) and the auxiliary sweep gas flow of 10 (arbitrary unit). The collision gas was helium with normalized collision energy of 30\% for fluoxetine and 35\% for norfluoxetine. A precursor ion (MS1), and two product ions (MS2 and MS3) were obtained, as following: fluoxetine $(\mathrm{m} / \mathrm{z} 310 \rightarrow \mathrm{m} / \mathrm{z}$ $148 \rightarrow \mathrm{m} / \mathrm{z}$ 117) e norfluoxetine $(\mathrm{m} / \mathrm{z} 296 \rightarrow \mathrm{m} / \mathrm{z} 134 \rightarrow \mathrm{m} / \mathrm{z} 117)$.

\subsection{Statistical analysis}

Complete statistical analyses were performed using GraphPad Prism (6.01, GraphPad Software, Inc., San Diego, USA). To test whether the dataset was of Gaussian distribution, D'Agostino-Pearson normality test was used. Since most of the data set was not normally distributed, with non-homogeneous variances, nonparametric tests were applied. For the comparison of fluoxetine, norfluoxetine and their sum between different exposure days, Kruskal-Wallis test with Dunns post-test were used. The statistical significance level was set to $\mathrm{p}<0.05$.

\section{Results and discussion}

\subsection{Method validation}

The validation of the method (Table 1 ) was performed to assure high quality analytical measurements and encompassed different performance criteria such as sensitivity, linear range, matrix effects, accuracy, and precision. Linearity was assessed using standard solutions and matrix-matched calibrations by analysing in triplicate at six concentration levels, between 2.5 and $50 \mathrm{ng} \mathrm{mL}^{-1}$, that correspond, according to the analytical methodology, to the range of $2.5-50 \mathrm{ng} \mathrm{g}^{-1}$, evaluated in matrix-matched linearity. Linearity was achieved for every compound, in the working standard solutions as confirmed by the correlation coefficient $\left(r^{2}\right)$, of 0.9999 , obtained in the calibration curves, for both fluoxetine and norfluoxetine. In matrix-matched solutions, $r^{2}$ values of 0.9999 were also obtained.

Matrix effects (ME) equalled the percentage of the matrixmatched calibration slope (B) divided by the slope of the standard calibration in solvent $(A)$. Thus, the ratio $(B / A \times 100)$ was defined as the absolute matrix effect (ME\%). The obtained value was interpreted as follows: a value of $100 \%$ denoted an absence of matrix effects, above 100\% signal enhancement and below 100\% signal suppression. Matrix effects for fluoxetine and norfluoxetine were considered negligible, since the values were of 98.59 and $100.00 \%$, respectively.

The method detection limits (MDL) and method quantification limits (MQL) were calculated through the matrix-matched calibration curve as $\left|3.3 \mathrm{~S}_{\mathrm{y} / \mathrm{x}}\right| / \mathrm{b}$ and $\left|10 \mathrm{~S}_{\mathrm{y} / \mathrm{x}}\right| / \mathrm{b}$, respectively, where $\mathrm{b}$ is the slope and $S_{y / x}$ the residual standard deviation of the linear function. Fluoxetine showed MDL and MQL values of 0.69 and $2.09 \mathrm{ng} \mathrm{g}^{-1}$ dry weight, respectively, and norfluoxetine of 0.81 and
$2.45 \mathrm{ng} \mathrm{g}^{-1}$ d.w., respectively.

For accuracy and repeatability assays, recoveries were determined in triplicate, at three different spiking levels, 5, 25 and $50 \mathrm{ng} \mathrm{g}^{-1}$, in three different days, and each extract was analysed three times. For fluoxetine, accuracy varied between 90.55 and 99.76\% with intra-day and inter-day repeatability (RSD \%) below 0.77 and $10.06 \%$, respectively. For norfluoxetine, accuracy varied between 85.78 and $99.35 \%$, with intra-day and inter-day repeatability below and 2.35 and $1.46 \%$, respectively.

\subsection{Frequency, uptake and metabolization by M. galloprovincialis}

The results showed that neither fluoxetine nor norfluoxetine was detected in un-exposed mussels. On the contrary, as presented in Fig. 1, in mussels exposed to fluoxetine at $75 \mathrm{ng} \mathrm{L}^{-1}$ (nominal concentration), fluoxetine, and norfluoxetine were detected and concentrations increased with the time of exposure. After 3 days of exposure, fluoxetine was detected in $70 \%$ of the samples with a mean of $2.53 \mathrm{ng} \mathrm{g}^{-1} \mathrm{~d}$.w., while norfluoxetine was found in only one sample (10\%), at $3.06 \mathrm{ng} \mathrm{g}^{-1} \mathrm{~d} . \mathrm{w}$. At day 7 , the frequency of detection in the samples increased to 80 and 50\%, for fluoxetine and norfluoxetine, respectively, as well as their mean levels, 4.43 and $2.85 \mathrm{ng} \mathrm{g}^{-1}$ d.w., respectively. By day 15 , the mean concentration of fluoxetine and of norfluoxetine was 9.31 and $11.65 \mathrm{ng} \mathrm{g}^{-1}$ d.w., respectively. Maximum fluoxetine and norfluoxetine concentrations of 23.81 and $24.10 \mathrm{ng} \mathrm{g}^{-1}$ d.w. were detected in M. galloprovincialis after 15 days of exposure. The sum of fluoxetine and norfluoxetine in mussel tissues reached a maximum concentration of $47.91 \mathrm{ng} \mathrm{g}^{-1}$ d.w.

Statistical analysis, using Kruskal-Wallis test with Dunns posttest (setting $p<0.05$ ), showed significant differences between days 3 and $15(p=0.0021)$ for fluoxetine, and between days 7 and 15 $(p=0.0041)$ and between days 3 and $15(p<0.0001)$, for norfluoxetine.

Although the absence of fluoxetine or norfluoxetine was not verified one could assume that, the seawater used did not contribute for the bioconcentration of fluoxetine nor norfluoxetine in mussels since neither one was detected in un-exposed (control) mussels. On the other hand, regarding the possible transformation of the fluoxetine added to the tanks into norfluoxetine, eventhough the concentration of norfluoxetine was not confirmed in the aqueous phase, according to Kwon and Armbrust (2006), who conducted a study on the fate and the persistence of fluoxetine under laboratory conditions, fluoxetine is recalcitrant to photolysis, hydrolysis, and microbial degradation. In the above-mentioned study, samples were placed in the dark and/or in a growth chamber fitted with fluorescent lamps simulating the ultraviolet output of sunlight. Over a period of 30 days (note that our study was conducted during a lower period of 15 days and that the water was changed every $48 \mathrm{~h}$ and fluoxetine concentration re-established) fluoxetine was hydrolytically and photolytically stable in all aqueous solutions used ( $\mathrm{pH} 5,7$, and 9) (note that our study was conducted at a $\mathrm{pH}$ of 8 ) except synthetic humic water ( $\mathrm{pH} 7$ ). Based on results of ready-biodegradability investigations, fluoxetine would not be expected to rapidly biodegrade in wastewater treatment plants. A photoproduct, norfluoxetine, was detected only in a

Table 1

Performance data obtained for fluoxetine and norfluoxetine in mussels spiked samples.

\begin{tabular}{|c|c|c|c|c|c|c|c|c|c|c|c|c|c|}
\hline \multirow[t]{2}{*}{ SSRI } & \multirow{2}{*}{$\begin{array}{l}\text { Matrix matched linearity } \\
\left(r^{2}\right)\end{array}$} & \multirow{2}{*}{$\begin{array}{l}\text { MDL } \\
\left(\mathrm{ng} \mathrm{g}^{-1}\right)\end{array}$} & \multirow{2}{*}{$\begin{array}{l}\mathrm{MQL} \\
\left(\mathrm{ng} \mathrm{g}^{-1}\right)\end{array}$} & \multirow[t]{2}{*}{ ME (\%) } & \multicolumn{3}{|c|}{ Recovery (\%) } & \multicolumn{3}{|c|}{ RSD within-day (\%) } & \multicolumn{3}{|c|}{ RSD between-day (\%) } \\
\hline & & & & & $5 \mathrm{ng} \mathrm{g}^{-1}$ & $25 \mathrm{ng} \mathrm{g}^{-1}$ & $50 \mathrm{ng} \mathrm{g}^{-1}$ & $5 \mathrm{ng} \mathrm{g}^{-1}$ & $25 \mathrm{ng} \mathrm{g}^{-1}$ & $50 \mathrm{ng} \mathrm{g}^{1}$ & $5 \mathrm{ng} \mathrm{g}^{-1}$ & $25 \mathrm{ng} \mathrm{g}^{-1}$ & ${ }^{1} 50 \mathrm{ng} \mathrm{g}^{-1}$ \\
\hline Fluoxetine & 0.9999 & 0.69 & 2.09 & 98.59 & 90.55 & 91.31 & 99.76 & 0.16 & 0.77 & 0.71 & 10.06 & 0.84 & 0.55 \\
\hline Norfluoxetine & 0.9999 & 0.81 & 2.45 & 100.00 & 85.78 & 95.39 & 99.35 & 2.35 & 0.05 & 1.94 & 1.46 & 1.19 & 0.27 \\
\hline
\end{tabular}



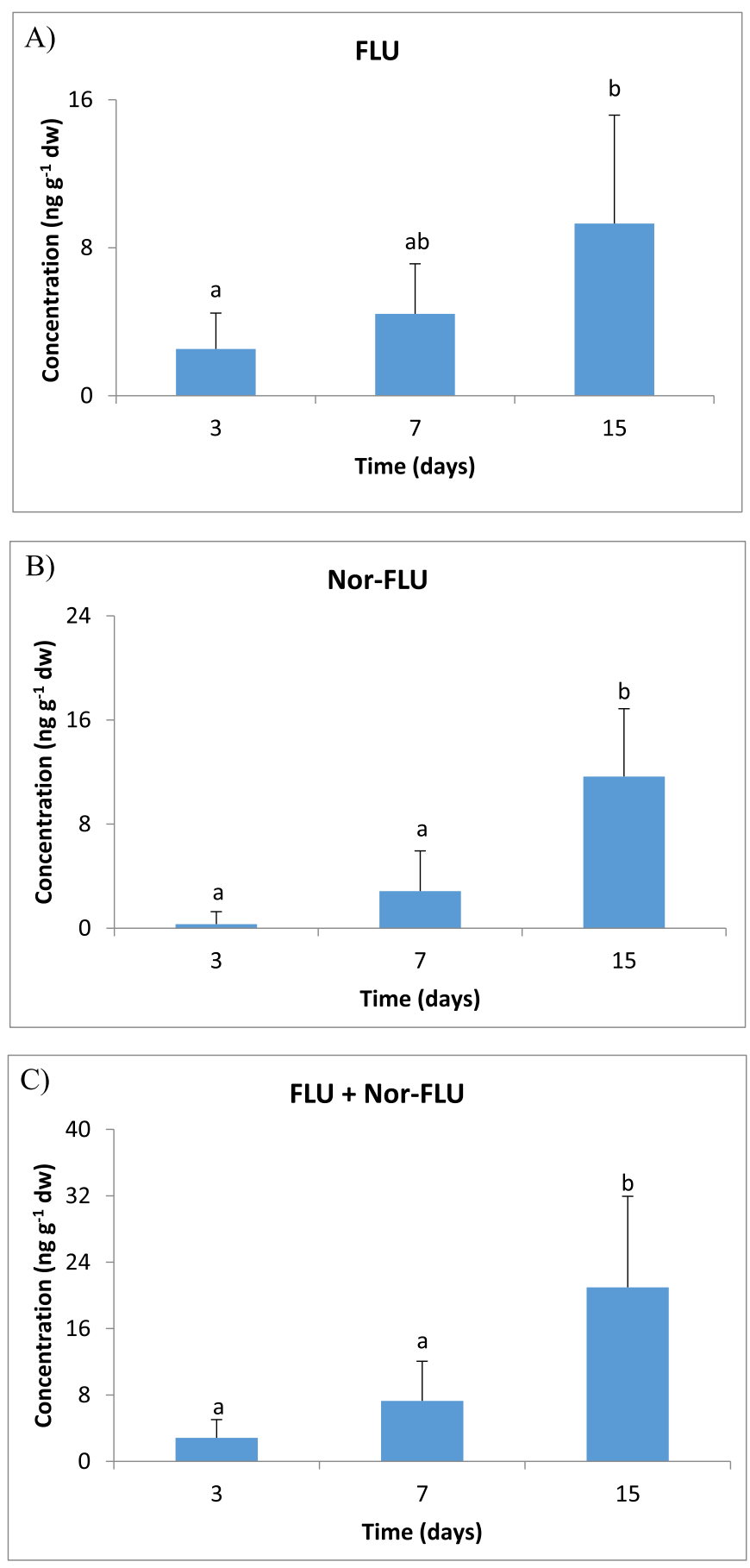

Fig. 1. Fluoxetine (A), norfluoxetine (B) and their sum (C) accumulated in M. galloprovincialis in different exposure days. Values are expressed as the mean \pm SD $(\mathrm{n}=10)\left(\mathrm{ng} \mathrm{g}^{-1}\right.$ d.w.). Different letters express significant differences $(\mathrm{p}<0.05)$.

sample of synthetic humic water and was identified as norfluoxetine formed by demethylation. Moreover, Méndez-Arriaga et al. (2011), also stated that photolysis of fluoxetine is remarkable only under alkaline $\mathrm{pH}$.

A rapid uptake of fluoxetine via waterborne exposure across the gills of mussels, presumably through feeding and respiratory activities, probably took place (Franzellitti et al., 2014). Detectable levels of fluoxetine were also observed by Franzellitti et al. (2014) in mussels whole tissues (digestive gland, gills and mantle/gonads) exposed for 7 days to 30 and $300 \mathrm{ng} \mathrm{L}^{-1}$ of this SSRI. The rank order of fluoxetine accumulation in tissues was: digestive gland $\geq$ gills $>$ mantle/gonads, varying between 8.43 and $25.01 \mathrm{ng} \mathrm{g}^{-1}$ w.w. and between 57.10 and $192.89 \mathrm{ng} \mathrm{g}^{-1}$ w.w., for the lower and higher exposure levels, respectively.

Bringolf et al. (2010) also observed that, only after 14 days of exposure, caged mussels at stream sites near a municipal WWTP effluent discharge accumulated substantial quantities of fluoxetine in their tissues. Fluoxetine concentrations measured in mussels from a WWTP effluent channel (maximum of $119 \mathrm{ng} \mathrm{L}^{-1}$ ) and from downstream sites, were of 79.1 and $9.8 \mathrm{ng} \mathrm{g}^{-1}$ w.w., respectively.

Taking into account that the water content of raw mussels is about 82.5\% (INSA, 2015), both of the above-mentioned studies report levels higher than the ones of the present work, nonetheless, in these studies, measurements of fluoxetine were performed in mussels depurated for only 3 days (Franzellitti et al., 2014) or not depurated at all (Bringolf et al., 2010).

Comparison between species, for instance mussels and fish, might be hampered by distinct lipid contents that may contribute for different accumulation patterns of the lipophilic fluoxetine (Gust et al., 2009). Even so, the first data that regarded fluoxetine and norfluoxetine accumulation in brain, liver, and muscle of different fish species of effluent-dominated ecosystems was reported by Brooks et al. (2005). Among the three fish species examined, average norfluoxetine levels were higher than fluoxetine. In decreasing order, norfluoxetine was found at $10.27 \mathrm{ng} \mathrm{g}^{-1}$ in liver, at $8.86 \mathrm{ng} \mathrm{g}^{-1}$ in brain, and at $1.07 \mathrm{ng} \mathrm{g}^{-1}$ in muscle tissues, whereas fluoxetine was present at $1.34,1.58$, and $0.11 \mathrm{ng} \mathrm{g}^{-1}$, respectively. These observations were also made by other researchers (Lajeunesse et al., 2011; Metcalfe et al., 2010; Ramirez et al., 2009, 2007; Schultz et al., 2010). Similarly, Gelsleichter and Szabo (2013) could only measure norfluoxetine, not fluoxetine, at $4.08 \mathrm{ng} \mathrm{mL} \mathrm{m}^{-1}$, in the plasma of bull sharks (Carcharhinus leucas) inhabiting a wastewater-impacted river. In contrast, Chu and Metcalfe (2007) reported lower concentrations of norfluoxetine ( $0.27 \mathrm{ng} \mathrm{g}^{-1}$ w.w.) than of fluoxetine $\left(0.37 \mathrm{ng} \mathrm{g}^{-1}\right.$ w.w.) in fish tissues collected from an harbour heavily impacted by discharges from municipal WWTPs.

In our study, norfluoxetine levels were lower than those of fluoxetine during the first week of exposure. However, by the end of the exposure period levels were slightly higher than those of fluoxetine. The ratio of norfluoxetine and fluoxetine were $0.12,0.64$ and 1.25 at 3, 7 and 15 days of exposure, respectively. These results suggest that the fluoxetine accumulated in mussel tissues is likely to be metabolised into norfluoxetine with the increase of fluoxetine accumulation and with the time of exposure.

As far as we know this is the first study that suggests the metabolization of fluoxetine in mussels, therefore comparison with other studies is difficult. Moreover, depending on the species, cytochrome P-450 dependent monooxygenase biotransforms, at different rates, fluoxetine into norfluoxetine (Gust et al., 2009). Indeed, in freshwater fish Japanese medaka (Oryzias latipes) exposed to fluoxetine ( $640 \mathrm{ng} \mathrm{L}^{-1}$ ) for 7 days, norfluoxetine concentrations were below those measured for fluoxetine until day 7 , when the average concentration of the metabolite $\left(64.3 \pm 8.7 \mathrm{ng} \mathrm{g}^{-1}\right.$ w.w.) was higher than that of for fluoxetine $\left(40.8 \pm 5.0 \mathrm{ng} \mathrm{g}^{-1}\right.$ w.w.) (Paterson and Metcalfe, 2008). A ratio of norfluoxetine to fluoxetine of approximately 2 was reported. On the other hand, Nakamura et al. (2008) found ratios of norfluoxetine and fluoxetine of 5.3 and 1.1 in the whole body of the fish Japanese medaka when exposed to $30 \mu \mathrm{g} \mathrm{L}^{-1}$ and $300 \mu \mathrm{g} \mathrm{L}-1$, respectively, of this SSRI, for 30 days.

One should also note that, since fluoxetine is a weak base (pKa 10.05), and the neutral form dominates at $\mathrm{pH}$ values near its $\mathrm{pKa}$ and the cationic form dominates at lower $\mathrm{pH}$ values, accumulation 
and toxicity is influenced by the pH of the water (Metcalfe et al., 2010; Ramirez et al., 2009). In fact, in vitro, the ratio of nonionized species increased for fluoxetine by a factor of 100 when increasing the $\mathrm{pH}$ from 7 to 9 . This could be also observed in fish where the accumulation of fluoxetine and its major metabolite norfluoxetine was multiplied while $\mathrm{pH}$ was elevated (Nakamura et al., 2008).

\subsection{Fluoxetine BCFs and norfluoxetine pseudo-BCFs}

A bioconcentration factor (BCF) is calculated as the ratio between the concentration of the compound of interest in the biota and that in the surrounding media (Zenker et al., 2014) and is commonly used in risk assessment analysis.

The BCF was calculated based on accumulation of fluoxetine in each mussel and the nominal water concentration $\left(75 \mathrm{ng} \mathrm{L}^{-1}\right)$ (Nakamura et al., 2008). Fluoxetine was detected in $70 \%$ of the mussels only after 3 days of exposure. The BCFs calculated were 34,59 , and 124 , at 3, 7 and 15 days, respectively, which corresponds to a $\log$ BCF between 1.5 and 2.1. Moreover a first order kinetic model was applied to the data and revealed that the steady state would only be reached after 52 days of exposure and that kinetic BCF (calculated as the ratio of the uptake and elimination rate constants) (Mackay and Fraser, 2000) was 129. Paterson and Metcalfe (2008) also estimated a kinetic BCF of 80 in the Japanese medaka exposed to a nominal fluoxetine concentration of $640 \mathrm{ng} \mathrm{L}^{-1}$. Fluoxetine octanol-water partition coefficient (Log Kow) ranges from 1.25 to 4.3 at $\mathrm{pH}$ ranging from 2 to 11 (Brooks et al., 2003). Estimating from these data, the log Kow for $\mathrm{pH} 8$ is 2.4 , and BCFs were much lower than those obtained in this study suggesting, as pointed out by Paterson and Metcalfe (2008), the limited utility of log Kow for estimating the fluoxetine BCF in mussels.

Norfluoxetine, like some other SSRI metabolites, is less polar than its parent compound being therefore more prone to accumulation than fluoxetine, and capable of eliciting the same or even worse biological effects (Gelsleichter and Szabo, 2013). The pseudoBCF value for norfluoxetine (calculated based on the concentration of norfluoxetine detected in each mussel and the nominal water concentration of fluoxetine ( $75 \mathrm{ng} \mathrm{L}^{-1}$ ) in water (Nakamura et al., 2008)) was of 4,38 and 155 , for days 3,7 and 15 , respectively. The pseudo-BCF value at day 15 was higher than the BCF value of fluoxetine $(\log B C F=2.2)$. The kinetic model applied indicated that the elimination rate was much longer than that of fluoxetine. This suggests the active metabolism of fluoxetine may have implications on mussel's health.

Considering both forms together, the pseudo-BCFs were 38, 97, and 399 for 3, 7 and 15 days respectively. The BCFs of fluoxetine were $<1500$ which suggest low accumulation potential but it does not rule out the capacity of fluoxetine to induce biological effects as those observed by Gonzalez-Rey and Bebianno (2013). To our knowledge, this is the first BCF reported for the sum of fluoxetine and its metabolite in mussels.

Recently, Franzellitti et al. (2014) reported higher BCFs values for fluoxetine ranging from 200 to 800 in M. galloprovincialis, after a 7 day treatment with 30 and $300 \mathrm{ng} \mathrm{L}^{-1}$. Paterson and Metcalfe (2008) also reported higher BCF and pseudo-BCF values for fluoxetine and norfluoxetine, after 7 day exposure, of 74 and 117, respectively, when Japanese medaka was exposed at a nominal concentration of fluoxetine of $640 \mathrm{ng} \mathrm{L}^{-1}$. Nonetheless, our results are consistent with the pseudo-BCFs of 170 calculated for the Japanese medaka calculated by Nakamura et al. (2008) for exposures at the same $\mathrm{pH}$ of the present study ( $\mathrm{pH} 8.1$ ). A lower norfluoxetine pseudo-BCF, of approximately 60 , was calculated for fathead minnows (Pimephales promelas) caged for 14 days in the Grand River downstream of a WWTP by Metcalfe et al. (2010). Nakamura et al. (2008) also determined the distribution coefficients in 1-octanol/ water (Dow) and liposome/water (Dlip-wat) of fluoxetine at a range of $\mathrm{pH}$ between 7 and $9(4.6 \pm 0.6 \times 102$ and $2.4 \pm 0.8 \times 104$ respectively at $\mathrm{pH} 8$ ) and concluded that Dlip-wat was less variable with $\mathrm{pH}$ than Dow and therefore more likely to be used to predict fluoxetine accumulation potential while no changes were observed for norfluoxetine.

\subsection{Links between biological effects in mussels M. galloprovincialis and BCFs ratios}

The presence of fluoxetine has been previously associated to promote the enhancement of lipid peroxidation (LPO) in mussels' digestive gland (5-fold higher than control), as well as a small increase of antioxidant enzyme catalase and phase II glutathione-Stransferase activities after 15 days of exposure to the same fluoxetine concentration (75 $\mathrm{ng} \mathrm{L}^{-1}$ ) (Gonzalez-Rey and Bebianno, 2013). Previously to that time period, the results concerning the antioxidant system response and associated damage were not significantly different from the control (Gonzalez-Rey and Bebianno, 2013). As mentioned above, the presence of norfluoxetine is considered to be potentially more damaging than fluoxetine alone for biota (Gelsleichter and Szabo, 2013). The observed damage and antioxidant response increased in fluoxetine-exposed mussels after 15 days (Gonzalez-Rey and Bebianno, 2013) which coincides with the time frame when the concentrations of norfluoxetine surpass those of the parental compound. This suggests that these effects may be due to the biotransformation of fluoxetine to norfluoxetine potentiating its effects on non-target organisms.

\section{Conclusions}

Overall, the data suggests that the fluoxetine accumulated in the marine mussels $M$. galloprovincialis is metabolized into norfluoxetine. Both accumulation and metabolization increased along the exposure period with significant differences between days 3 and 15 for fluoxetine, and between days 7 and 15 and days 3 and 15, for norfluoxetine. The BCFs calculated were 34,59 , and 124, at 3, 7 and 15 days, respectively, and the pseudo-BCF values for norfluoxetine were 4, 38 and 155 for 3, 7 and 15 days respectively. The steady state would only be reached after 52 days of exposure and the kinetic BCF of fluoxetine was of 129 . Since norfluoxetine is more active than fluoxetine, and its pseudo-BCF is higher than fluoxetine $\mathrm{BCF}$, at day 15 , presumably this metabolization potentiates the biological effects on mussels. Considering the toxicity assays already developed, it is expected that at environmental measured concentrations, toxicity effects may occur.

Additionally the presence of SSRIs in the aquatic environment is commonly associated with the impact of municipal wastewater effluents, where these compounds are generally present as mixtures in surface waters. Therefore, further studies should be focused on monitoring the uptake of the mixture of these antidepressants by mussels, as expected, good indicators of the presence of these pharmaceuticals.

\section{Funding sources}

This work was funded by Fundação para a Ciência e a Tecnologia (FCT), through the projects vPEst-OE/SAU/UI0177/2011, PTDC/AACAMB/120889/2010 and UID/QUI/50006/2013. L. J. G. Silva (SFRH/ BPD/62877/2009) and M. Gonzalez-Rey (SFRH/BD/41606/2007) were granted by fellowships from FCT. M. J. Bebianno would like to thank the support of EMECORISK: "Effect of emerging contaminants in aquatic ecosystems" of 0432-I2TEP-5-E (I2TEP) project and 
FP7-People-2009-IRSES GENERA project. The authors would like to thank Dr Luis Nunes for its help in kinetic modelling of fluoxetine.

\section{Acknowledgements}

The authors thank Fundação para a Ciência e a Tecnologia (FCT), through the projects vPEst-OE/SAU/UI0177/2011, PTDC/AAC-AMB/ $120889 / 2010$ and UID/QUI/50006/2013, the financial support, and the fellowship granted to L. J. G. Silva (SFRH/BPD/62877/2009) and to M. Gonzalez-Rey (SFRH/BD/41606/2007). The authors are also grateful to the Laboratory of Mass Spectrometry (LEM) of the Node UC integrated in the National Mass Spectrometry Network (RNEM) of Portugal, for the MS analysis, and to Fátima Nunes for all the assistance. Finally, we gratefully acknowledge Centro de Investigação Marinha e Ambiental (CIMA), Science and Technology Faculty, Algarve University; the exposure assays the help of $\mathrm{Dr}$ L. Nunes of the University of Algarve for the help in adjusting the kinetic model.

\section{Appendix A. Supplementary data}

Supplementary data related to this article can be found at http:// dx.doi.org/10.1016/j.envpol.2016.02.022.

\section{References}

Bebianno, M.J., Pereira, C.G., Rey, F., Cravo, a, Duarte, D., D'Errico, G., Regoli, F., 2015. Integrated approach to assess ecosystem health in harbor areas. Sci. Total Environ. 514, 92-107.

Bossus, M.C., Guler, Y.Z., Short, S.J., Morrison, E.R., Ford, A.T., 2014. Behavioural and transcriptional changes in the amphipod Echinogammarus marinus exposed to two antidepressants, fluoxetine and sertraline. Aquat. Toxicol. 151, 46-56.

Boxall, A.B.A., Rudd, M.A., Brooks, B.W., Caldwell, D.J., Choi, K., Hickmann, S., Innes, E., Ostapyk, K., Staveley, J.P., Verslycke, T., Ankley, G.T., Beazley, K.F., Belanger, S.E., Berninger, J.P., Carriquiriborde, P., Coors, A., DeLeo, P.C., Dyer, S.D., Ericson, J.F., Gagné, F., Giesy, J.P., Gouin, T., Hallstrom, L., Karlsson, M.V. Larsson, D.G.J., Lazorchak, J.M. Mastrocco, F. McLaughlin, A., McMaster, M.E. Meyerhoff, R.D., Moore, R., Parrott, J.L., Snape, J.R., Murray-Smith, R., Servos, M.R., Sibley, P.K., Straub, J.O., Szabo, N.D., Topp, E., Tetreault, G.R. Trudeau, V.L., Van Der Kraak, G., 2012. Pharmaceuticals and personal care products in the environment: what are the big questions? Environ. Health Perspect. 120, 1221-1229.

Bringolf, R.B., Heltsley, R.M., Newton, T.J., Eads, C.B., Fraley, S.J., Shea, D., Cope, W.G. 2010. Environmental occurrence and reproductive effects of the pharmaceutical fluoxetine in native freshwater mussels. Environ. Toxicol. Chem. 29, 1311-1318.

Brooks, B.W., Foran, C.M., Richards, S.M., Weston, J., Turner, P.K., Stanley, J.K. Solomon, K.R., Slattery, M., La Point, T.W., 2003. Aquatic ecotoxicology of fluoxetine. Toxicol. Lett. 142, 169-183.

Brooks, B.W., Kevin Chambliss, C., Stanley, J.K., Ramirez, A., Banks, K.E., Johnson, R.D., Lewis, R.J., 2005. Determination of select antidepressants in fish from an effluent-dominated stream. Environ. Toxicol. Chem. 24, 464-469.

Chu, S., Metcalfe, C.D., 2007. Analysis of paroxetine, fluoxetine and norfluoxetine in fish tissues using pressurized liquid extraction, mixed mode solid phase extraction cleanup and liquid chromatography-tandem mass spectrometry. J. Chromatogr. A 1163, 112-118.

Dodder, N.G., Maruya, K. a, Lee Ferguson, P., Grace, R., Klosterhaus, S., La Guardia, M.J., Lauenstein, G.G., Ramirez, J., 2014. Occurrence of contaminants of emerging concern in mussels (Mytilus spp.) along the California coast and the influence of land use, storm water discharge, and treated wastewater effluent. Mar. Pollut. Bull. 81, 340-346.

Du, B., Haddad, S.P., Scott, W.C., Chambliss, C.K., Brooks, B.W., 2015. Pharmaceutica bioaccumulation by periphyton and snails in an effluent-dependent stream during an extreme drought. Chemosphere 119, 927-934.

Fong, P.P., Ford, A.T., 2014. The biological effects of antidepressants on the molluscs and crustaceans: a review. Aquat. Toxicol. 151, 4-13.
Franzellitti, S., Buratti, S., Capolupo, M., Du, B., Haddad, S.P., Chambliss, C.K., Brooks, B.W., Fabbri, E., 2014. An exploratory investigation of various modes of action and potential adverse outcomes of fluoxetine in marine mussels. Aquat. Toxicol. 151, 14-26.

Gelsleichter, J., Szabo, N.J., 2013. Uptake of human pharmaceuticals in bull sharks (Carcharhinus leucas) inhabiting a wastewater-impacted river. Sci. Total Environ. 456-457, 196-201.

Gonzalez-Rey, M., Bebianno, M.J., 2013. Does selective serotonin reuptake inhibitor (SSRI) fluoxetine affects mussel Mytilus galloprovincialis? Environ. Pollut. 173, 200-209.

Gust, M., Buronfosse, T., Giamberini, L., Ramil, M., Mons, R., Garric, J., 2009. Effects of fluoxetine on the reproduction of two prosobranch mollusks: potamopyrgus antipodarum and Valvata piscinalis. Environ. Pollut. 157, 423-429.

INSA, 2015. Tabela da Composição de Alimentos (TCA) [WWW Document]. Inst. Nac. dr. Ricardo Jorge, Ministério da Saúde, Port. URL. http://www.insa.pt/sites/INSA/ Portugues/AreasCientificas/AlimentNutricao/AplicacoesOnline/ TabelaAlimentos/PesquisaOnline/Paginas/DetalheAlimento.aspx?ID=IS909 (accessed 06.30.15).

Kreke, N., Dietrich, D.R., 2008. Physiological endpoints for potential SSRI interactions in fish. Crit. Rev. Toxicol. 38, 215-247.

Kwon, J.-W., Armbrust, K.L., 2006. Laboratory persistence and fate of fluoxetine in aquatic environments. Environ. Toxicol. Chem. 25, 2561-2568.

Lajeunesse, A., Gagnon, C., Gagné, F., Louis, S., Cejka, P., Sauvé, S., 2011. Distribution of antidepressants and their metabolites in brook trout exposed to municipal wastewaters before and after ozone treatment-evidence of biological effects. Chemosphere 83, 564-571.

Mackay, D., Fraser, A., 2000. Bioaccumulation of persistent organic chemicals: mechanisms and models. Environ. Pollut. 110, 375-391.

Maruya, K. a, Dodder, N.G., Weisberg, S.B., Gregorio, D., Bishop, J.S., Klosterhaus, S., Alvarez, D. a, Furlong, E.T., Bricker, S., Kimbrough, K.L., Lauenstein, G.G., 2014 The mussel watch California pilot study on contaminants of emerging concern (CECs): synthesis and next steps. Mar. Pollut. Bull. 81, 355-363.

Méndez-Arriaga, F., Otsu, T., Oyama, T., Gimenez, J., Esplugas, S., Hidaka, H., Serpone, N., 2011. Photooxidation of the antidepressant drug Fluoxetine (Prozac $($ ) in aqueous media by hybrid catalytic/ozonation processes. Water Res. 45, 2782-2794.

Metcalfe, C.D., Chu, S., Judt, C. Li, H., Oakes, K.D., Servos, M.R., Andrews, D.M., 2010 Antidepressants and their metabolites in municipal wastewater, and downstream exposure in an urban watershed. Environ. Toxicol. Chem. 29, 79-89.

Nakamura, Y., Yamamoto, H., Sekizawa, J., Kondo, T., Hirai, N., Tatarazako, N., 2008. The effects of $\mathrm{pH}$ on fluoxetine in Japanese medaka (Oryzias latipes): acute toxicity in fish larvae and bioaccumulation in juvenile fish. Chemosphere 70, 865-873.

Paterson, G., Metcalfe, C.D., 2008. Uptake and depuration of the anti-depressant fluoxetine by the Japanese medaka (Oryzias latipes). Chemosphere 74, 125-130.

Ramirez, A.J., Brain, R.A.S., Usenko, S., Mottaleb, M.A., O'Donnel, J.G., Stahl, L.L., Wathen, J.B., Snyder, B.D.I., Pitt, J.L., Perez-Hurtado, P., Dobbins, L.L., Brooks, B.W., Chambliss, C.K., 2009. Occurrence of pharmaceuticals and personal care products in fish: results of a national pilot study in the United States. Environ. Toxicol. Chem. 28, 2587-2597.

Ramirez, A.J., Mottaleb, M. a, Brooks, B.W., Chambliss, C.K., 2007. Analysis of pharmaceuticals in fish using liquid chromatography-tandem mass spectrometry. Anal. Chem. 79, 3155-3163.

Schultz, M.M., Furlong, E.T., 2008. Trace analysis of antidepressant pharmaceuticals and their select degradates in aquatic matrixes by LC/ESI/MS/MS. Anal. Chem. $80,1756-1762$.

Schultz, M.M., Furlong, E.T., Kolpin, D.W., Werner, S.L., Schoenfuss, H.L., Barber, L.B., Blazer, V.S., Norris, D.O., Vajda, A.M., 2010. Antidepressant pharmaceuticals in two U.S. effluent-impacted streams: occurrence and fate in water and sediment, and selective uptake in fish neural tissue. Environ. Sci. Technol. 44, 1918-1925.

Silva, L.J.G., Lino, C.M., Meisel, L.M., Pena, A., 2012. Selective serotonin re-uptake inhibitors (SSRIs) in the aquatic environment: an ecopharmacovigilance approach. Sci. Total Environ. 437, 185-195.

Silva, L.J.G., Pereira, M.P.T., Meisel, L.M., Lino, C.M., Pena, A., 2015. Reviewing the serotonin reuptake inhibitors (SSRIs) footprint in the aquatic biota: uptake, bioaccumulation and ecotoxicology. Environ. Pollut. 197, 127-143.

Sumpter, J.P., Donnachie, R.L., Johnson, a C., 2014. The apparently very variable potency of the anti-depressant fluoxetine. Aquat. Toxicol. 151, 57-60.

Zenker, A. Cicerob, M.R., Prestinaci, F. Bottoni, P., Carere, M. 2014. Bioaccumulation and biomagnification potential of pharmaceuticals with a focus to the aquatic environment. J. Environ. Manage. 133, 378-387. 